\title{
DESIMINASI PEMBUATAN DESINFEKTAN SENDIRI BAHAN PENYEMPROTAN CEGAH COVID-19 DI KELURAHAN TANJUNG KRAMAT KOTA GORONTALO
}

\section{Desimination Of The Making Of Your Own Desinfectant Spraying Materials Prevent Covid- 19 In Tanjung Kramat Kelurahan, Kota Gorontalo}

Nurhafnita), Nur Fitriyanti Bulotio ${ }^{2)}$, Syaiful Umela ${ }^{3)}$

${ }^{1,2,3)}$ Program Studi Teknologi Hasil Pertanian, Politeknik Gorontalo

E-mail :ithawahid@ poligon.ac.id ${ }^{1)}$

\begin{abstract}
ABSTRAK
Stunting merupakan ancaman utama terhadap kualitas manusia Indonesia, juga ancaman terhadap kemampuan daya saing bangsa. Hal ini dikarenakan anak stunted, bukan hanya terganggu pertumbuhan fisiknya (bertubuh pendek/kerdil) saja, melainkan juga terganggu perkembangan otaknya, yang mana tentu akan sangat mempengaruhi kemampuan dan prestasi di sekolah, produktivitas dan kreativitas di usia-usia produktif. Perbaikan pola makan dengan mulai merintis menanam tanaman tinggi zat besi dan asam folat di pekarangan rumah (Daun kelor, daun bayam hijau dan daun ubi) juga diperlukan khususnya untuk memenuhi kebutuhan ibu hamil dan MPASI balita. Pemanfaatan budidaya secara vertikultur mampu mempermudah ibu rumah tangga untuk menyediakan sayuran untuk keluarganya. Dengan semakin mudahnya akses terhadap sayuran pencegah stunting maka ancaman terhadap stunting terhadap balita dapat dikurangi angka prevalensinya.
\end{abstract}

Kata kunci: Kata kunci: sayuran; pekarangan; stunting; makanan pendamping; balita

\begin{abstract}
Stunting is a major challenge to the quality of Indonesian people, as well as a threat to the nation's competitiveness. This is because children are stunted, not only hinder their physical growth (short / dwarf), but also improve brain development, which of course will greatly affect the ability and achievement in school, increase and increase productivity in productive periods. Improving diet by starting to plant high substances and folic acid in the yard (Moringa leaves, green spinach leaves and sweet potatoes) are also needed specifically to meet the needs ofpregnant women and MPASI toddlers. Farmers' homes to provide vegetables for households. Thus the more easy access to stunting prevention vegetables, the protection against stunting for infants can be calculated the prevalence rate.
\end{abstract}

Keywords: vegetables; yard; stunting; side dishes; toodler 


\section{PENDAHULUAN}

Covid-19 saat ini dinyatakan sebagai pandemic dunia oleh WHO. Coronavirus merupakan zoonosis atau virus yang ditularkan antara hewan dan manusia. Seperti kita ketahui virus ini berawal dari kota Wuhan, Cina sejak Desember 2019.

Indonesia termasuk dalam deretan negaranegara dengan angka kematian tertinggi di dunia. Laju kematian global sebesar 4,3\% sebagian besar mengenai kelompok usia lanjut $8 \neg 15 \%$ dan pasien dengan penyakit penyerta. Hal ini dapat menjadi suatu ancaman gangguan keamanan dan ketertiban di lingkungan masyarakat.

Dalam rangka penanganan cepat Covid-19 sesuai dengan Keputusan Presiden No. 7 Tahun 2020 tentang Gugus Tugas Percepatan Penanganan Corona yang bertujuan untuk meningkatkan ketahanan nasional dibidang kesehatan diperlukan langkah-langkah cepat yang dapat mengurangi dan memutus penyebaran COVID-19 sehingga angka kasus dan kematian dapat berkurang.

Dalam rangka penanganan cepat Covid-19 sesuai dengan Keputusan Presiden No. 7 Tahun 2020 tentang Gugus Tugas Percepatan Penanganan Corona yang bertujuan untuk meningkatkan ketahanan nasional dibidang kesehatan diperlukan langkah-langkah cepat yang dapat mengurangi dan memutus penyebaran COVID-19 sehingga angka kasus dan kematian dapat berkurang.

Masyarakat pada umumnya memiliki keterbatasan pengetahuan akan Covid baik efek penyakitnya, proses penyembuhannya maupun cara pencegahan penyakit tersebut.Padahal disekitar tempat tinggal masyarakat, mudah ditemui bahan- bahan yang dapat diolah sebagai alternatif pencegahan penularan covid. Hanya saja keterbatsan ilmu dan pengetahuan menjadi salah satu kendala selain rasa kurang peduli akan kesehatan diri sendiri maupun orang lain yang hidup berdampingan dengan masyarakat itu sendiri.

Kondisi saat ini, kasus positif covid-19 di Gorontalo semakin bertambah sehingga harus segera dilakukan antisipasi pada masyarakat melalui sosialisasi dan desiminasi pembuatan desinfektan secara individu mandiri maupun secara berkelompok.

\section{SOLUSI DAN TARGET LUARAN}

Berdasarkan analisis situasi dan kebutuhan,solusi yang ditawarkan untuk pemecahan masalah yaitu melalui program sosialisasi, desiminasi pembuayan desinfektan. Adapun kegiatan yang akan dilaksanakan yang berkaitan dengan solusi yang ditawarkan adalah:

1. Sosialisasi bahaya dan proses pengegahan covid 19.

2. Desiminasi pembuatan desinfektan sebagai pencegah penularan covid 19

\section{Target Luaran}

Luaran yang diharapkan adalah :

1. Menambah pengetahuan masyarakat tentang covid 19.

2. Meningkatkan kemampuan dan keterampilan masyarakat dalam pembuatan desinfektan secara mandiri.

3. Terjalinnya kerjasama antar pemerintah kelurahan setempat dengan POLIGON sebagai salah satu model kegiatan sosialisasi pengenalan kampus.

\section{METODE PELAKSANAAN KEGIATAN}

\section{Tempat dan Waktu Pengabdian}

Pengabdian ini telah dilaksanakan pada hari senin 27 April di kelurahan Tanjung Kramat Kecamatan Hulonthalangi kota Gorontalo. 


\section{Bahan dan Alat Pengabdian}

Bahan yang digunakan dalam kegiatan pengabdian pembuatan cairan desinfektan adalah sebagai berikut :

- Cairan pemutih

- Air

- Sereh

\section{Cara membuat}

1. Pengenceran 5 persen sodium hipoklorit dengan perbandingan 1:100. Gunakan 1 bagian bahan pemutih untuk 99 bagian air ledeng dingin (pengenceran 1:100). cairan pembersih lantai, memiliki bahan aktif yang lebih rendah dari cairan pemutih. Dengan demikian, dalam membuat disinfektan dari cairan pembersih lantai ini, dianjurkan perbandingannya tidak jauh berbeda antara cairan pembersih dan air.

2. Takarannya, 10 tutup botol cairan pembersih lantai diencerkan dengan 1 liter air. Hal tersebut untuk mendapatkan konsentrasi minimal 0,5 persen bahan aktif yakni monoterpen agar efektif sebagai desinfektan," Selain itu, dapat pula ditambahkan bahan pewangi alami, misalnya air hasil rebusan sereh untuk menetralkan bau karbol.

\section{HASIL DAN PEMBAHASAN}

Pengabdian Masyarakat yang dilaksanakan oleh Dosen Program Studi Teknologi Hasil Pertanian Politeknik Gorontalo di Kelurahan Tanjung Kramat

Kecamatan Hulontalangi Kota Gorontalo, memberikan pelatihan kepada kelompok masyarakat untuk pembuatan desinfektan secara mandiri dengan bahan dasar yang mudah diperoleh dan mudah penggunaannya.

Kegiatan dilaksanakan secara online menggunakan Zoom meetimg.

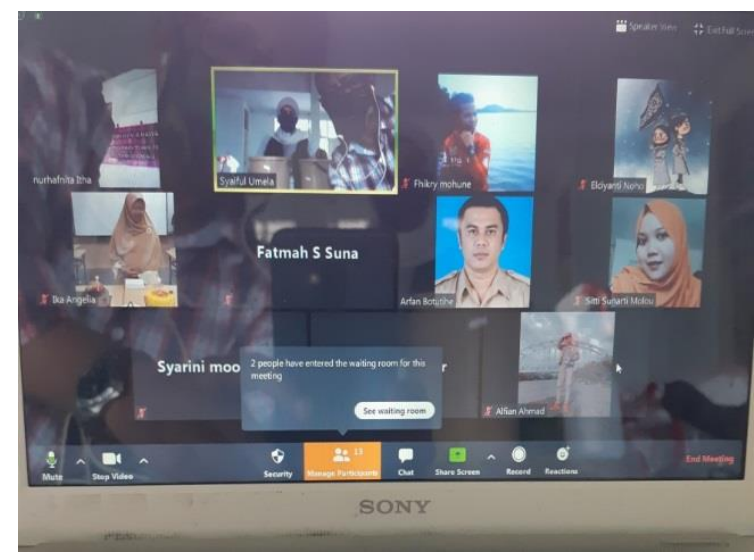

Gambar 1. Peserta Kegiatan Pengabdian Online via Zoom

Pelaksanaan kegiatan pengabdian dilakukan dalam beberapa tahap yakni:

1) Identifikasi masalah dan cara pemecahannya. Ternyata ada masalah kesulitan memperoleh dan mendapatkan desinfektan. Sehingga diperlukan tindakan pendampingan dalam pembuatan desinfektan bagi masyarakat Kelurahan Tanjung Kramat.

2) Koordinasi dengan pihak setempat Setelah berkoordinasikan kepada semua pihak yang akan dilibatkan terutama pihak pemerintah dan masyarakat Kelurahan Tanjung kramat. Disepakati kegiatan pengabdian masyarakat Dosen Politeknik Gorontalo dilaksanakan di Kelurahan Tanjung kramat.

3) Persiapan tim dan teknis pelaksanaan kegiatan yaitu mempersiapkan kebutuhan utama maupun kebutuhan pendukung pelaksanaan kegiatan. Kebutuhan utama kegiatan ini seperti materi sosialiasi serta alat bahan pembuatan desinfektan. Sedangkan kebutuhan pendukung seperti perangkat audio visual, absen peserta, konsumsi, dll. Teknis pelaksanaan kegiatan terdiri dari penyuluhan, praktek dan diskusi interaktif. 
4) Pelaksanaan kegiatan sosialisasi dan praktek (desiminasi) pembuatan desinfektan, terdiri dari :

- Penjelasan teori tentang bahan dan fungsinya.

- Peserta : masyarakat Kelurahan Tanjung kramat

- Media yang digunakan: pemaparan teori dalam bentuk power point secara online menggunakan aplikasi zoom meeting.

5) Evaluasi dan pembagian produk desinfektan yang telah dipresiapkan sebelumnya.

- Untuk melihat sejauh mana tujuan tercapai dan manfaat yang dirasakan oleh masyarakat Kelurahan Tanjung kramat sebagai target utama, serta melihat kekurangan selama proses pengabdian sehingga menjadi bahan perbaikan selanjutnya.

- Selain itu, kegiatan ini diakhiri dengan pembagian produk desinfektan kepada masyarakat untuk mencegah penyebaran virus Covid-19.

Selain itu, kegiatan ini diakhiri dengan pembagian produk desinfektan kepada masyarakat untuk mencegah penyebaran virus Covid-19

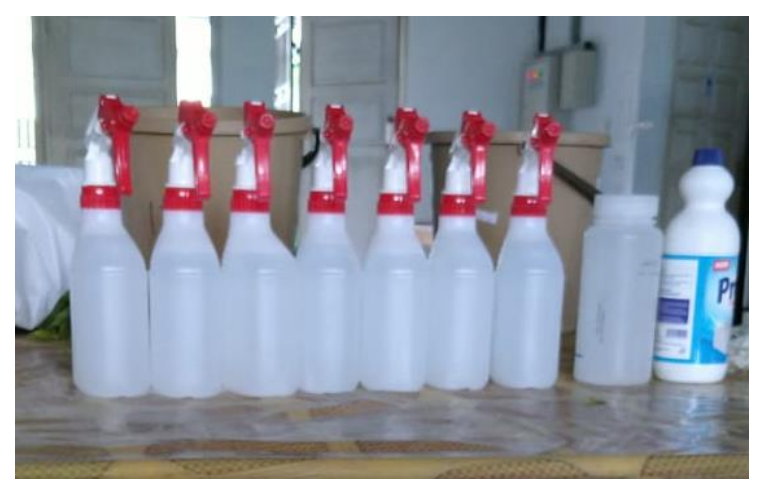

Gambar 2. Botol Semprot Desinfektan dan Bahan Dasar Sodium Hipoklorit

\section{KESIMPULAN}

Kesimpulan pada kegiatan pengabdian adalah terjalinnya kerjasama antar pemerintah kelurahan setempat dengan POLIGON sebagai salah satu model kegiatan sosialisasi pengenalan kampus. Dan dapat meningkatkan pengetahuan dan keterampilan masyarakat tentang pembuatan desinfektan. Pelatihan dan praktek cara pembuatan desinfektan diharpkan masyararakat dapat memutuskan mata rantai penyebaran virus covid 19 dengan menjaga jarak dan selalau menjaga kesehatan.

\section{UCAPAN TERIMA KASIH}

Terimakasih kepada Politeknik Gorontalo atas bantuan hibah pengabdian masyarakat tahun 2020

\section{DAFTAR PUSTAKA}

Dinas Kesehatan Provinsi Gorontalo, 2020. Data Perkembangan Pandemik Covid19 di Provinsi Gorontalo. www.dinkes.gorontaloprov.go.id/covi d-19. Akses : 20 April 2020.

Kompas.2020.https://www.kompas.com/tre $\mathrm{n} / \mathrm{read} / 2020 / 03 / 30 / 054700165 / \mathrm{membu}$ at-disinfektan-sendiri--cara-bahandan-hal-yang-harusdiperhatikan?page=all

Pusat Krisis Kesehatan Kemenkes 2020, Perkembangan Kasus Komulatif per $19 \quad$ April 2020. www.pusatkrisis.kemenkes.go.id. 20 April 2020Riskesdas. 2018. Riset Kesehatan Dasar 2013 